\title{
Tilgivelse - nøkkelen til et godt liv i familie, skole og samfunn?
}

Av Guro Hansen Helskog

Dosent i pedagogikk, Universitetet i Sørøst-Norge, pb.235, 3603 Kongsberg, guro.helskog@usn.no

Mens hat, hevntanker og bitterhet kan ødelegge livet både for en selv og andre, kan tilgivelse bidra til indre frihet, god helse og sunne relasjoner. Ikke bare i familien og $i$ klasserommet, men også på den storpolitiske arenaen. Kan tilgivelse rett og slett vore en fellesmenneskelig nøkkel til et godt liv, uavhengig av kontekst og livssynsmessig ståsted?

Det var våren 2007. Jeg hadde vært så heldig å få være med på å utvikle et kursprogram som har vist seg å være til god hjelp for foreldre som ønsker å skape et tilstrekkelig godt samarbeid omkring felles barn etter samlivsbrudd (Folkehelseinstituttet 2018). Nå var jeg i gang med forberedelsene til en oppfølgingskveld tre måneder etter et helgekurs. I en av bøkene jeg bladde i, kom jeg over et intervju med den tibetanske buddhistlederen Dalai Lama. Intervjuet beveget meg, og jeg noterte et utdrag som jeg bestemte meg for å dele med kursdeltakerne denne kvelden. Utdraget lyder som følger:

Selv om forsøket på å skape fred $i$ verden gjennom indre forvandling av enkeltmennesker er vanskelig, er det den eneste måten. (...) Jeg tror at kjorlighet, medfolelse og uselviskhet er det grunnleggende fundamentet for fred. Så snart disse egenskapene er utviklet hos ett menneske, er han eller hun $i$ stand til a skape en atmosfere av fred og harmoni. Denne atmosforen kan utvides fra enkeltmennesket til hans familie, fra familien til samfunnet, og etter hvert til hele verden ${ }^{1}$.

Kurset deltakerne gikk på, var tilrettelagt som en bearbeidings- og bevisstgjøringsprosess med fem hovedtemaer:

1. Bruddprosessen

2. Kommunikasjon, konflikt og samspill

3. Å se barnets livssituasjon

4. Foreldresamarbeid

5. Veien videre

Gjennom øktene fikk deltakerne mulighet til å reflektere over hva som var klokt å gjøre i situasjonen de sto i, med tanke på at livet skulle bli best mulig for barna, og også dem selv, ekspartner og andre berørte, på kort og lang sikt.

1 Jeg noterte dessverre ikke referansen den gangen, og har ikke klart å finne igjen boka intervjuet sto i. 
Allerede da deltakerne kom inn i rommet denne kvelden, kunne jeg se at kurset hadde virket i dem. Da de entret det samme rommet tre måneder tidligere, var de veldig preget av å leve i en krevende livssituasjon. Enkelte kom gråtende inn, andre så veldig slitne og medtatte ut, mens atter andre virket innbitte og sinte. Derfor både gledet og forundret jeg meg over smilene, lettheten og sinnsroen deltakerne nå spredte om seg. De fortalte at de hadde forsøkt å handle på innsikten de hadde fått, ved for eksempel å prøve ut nye måter å kommunisere på eller reagere på overfor ekspartner. Det hadde umiddelbart skapt positive endringer.

Vi reflekterte over hva som hadde skjedd. I et forsøk på å inspirere deltakerne til å se nærmere på egne tanke-, reaksjons- og handlingsmønstre, viste jeg dem sitatet fra Dalai Lama. I sitatet snakker han om mulighetene for en indre forvandling hos den enkelte. Forvandlingen innebærer utvikling av egenskaper som kjærlighet, medfølelse og uselviskhet, som kan gjøre hver enkelt av oss i stand til å skape en fredelig og harmonisk atmosfære rundt oss. Denne atmosfæren kan utvides fra enkeltmennesket til familien, fra familien til samfunnet, og til slutt til hele verden. Vi trenger ikke ta ham helt på ordet, understreket jeg, men er det likevel noe i det han sier som har relevans for hverdagsmennesker som oss? Det mente deltakerne bestemt at det hadde. Atmosfæren omkring barna og ungdommene var blitt mye bedre $\mathrm{i}$ tiden etter kurset, rett og slett fordi de hadde bestemt seg for å legge ned mest mulig av konflikten, og forholde seg til ekspartner på nye måter.

I refleksjonssamtalen kom vi inn på begrepene tilgivelse og forsoning. $\AA$ handle med nestekjærlighet, medfølelse og uselviskhet, involverer som regel også elementer av tilgivelse og forsoning, kom vi fram til. Hvis hat, sinne, bitterhet og uforsonlighet får prege forholdet foreldrene har til hverandre, vil det prege atmosfæren omkring barna også, med fare for å skade utviklingsmulighetene deres. $\AA$ forvandle negative følelser til mer positive krever derfor at man som voksen så langt det er mulig gjennomgår en indre forvandling og fornyelse som involverer tilgivelse.

Ikke bare det, tenker jeg nå, med støtte i empirisk forskning (Wade et al 2014). Evne til så langt det er mulig å tilgi, akseptere og forsone seg med det vonde som hender oss gjennom livet, er essensielt for å kunne skape et godt liv for oss selv og andre, noe ikke minst Horrobin (2009) proklamerer med ekstra stor kraft. Han oppfordrer den som lever med en opplevelse av urett, uansett hvor grov uretten er, til å tilgi likevel, rett og slett for å bli fri av de negative følelsene som holder personen igjen fra å leve et helt og fritt liv. Han sammenlikner livet vårt med et hus med mange forskjellige rom. Hvert av rommene er fylt med erfaringer og minner fra ulike hendelser i livet. Noen av dørene, skriver han, står vidåpne og vi kan glede oss over minnene i rommene. Andre dører er lukket, men vi åpner dem med letthet når vi selv ønsker det. Andre dører igjen, er lukket og låst: 
«Det er for smertefullt å se på det som ligger gjemt bak disse dorene. Ofte er nøkkelen kastet vekk. Disse rommene har ulike navn: traume. avvisning, svik, overgrep, manglende lojalitet, skilsmisse, ulykker og mange flere». Folk lever videre etter slike hendelser, og de vet at bak disse dorene ligger uforlost smerte som andre har påfort dem. Av og til kommer smerten fra feil de selv har gjort. Det smertefulle og innestengte kaoset siver av og til ut under dorene $i$ de avstengte rommene.

Nettopp derfor er tilgivelse så viktig, mener Horrobin. Som pastor kaller han det Guds universalnøkkel, men argumentene hans har paralleller også i sekulære sammenhenger. Forvandlingen som følger med tilgivelse, kan forstås som en frivillig og indre prosess hvor vi gir slipp på destruktive tanker og følelser, skriver for eksempel Meneses \& Greenberg (2019). Den indre forvandlingen innebærer at man tilgir både seg selv og den andre, og ellers aksepterer og forsoner seg med situasjonen slik den var blitt. Vi tilgir for å sette oss selv fri fra de destruktive sinnskreftene. Horrobin på sin side, løfter fram det han kaller den mektigste bønn på jord: «Far, tilgi dem, for de vet ikke hva de gjør» (Luk 23, 34).

Mens Horribin understreker at gevinsten av å klare å tilgi er så stor at det er verdt det uansett hvor grov overtredelsen er, vil andre hevde at det ikke er alt som kan eller skal tilgis. Noen overtredelser er rett og slett for grove. For å komme fri av det som har skjedd og å løsne bindingene til den som har skadet oss, kan det likevel være mulig å forsone seg med det som har skjedd og akseptere at livet har blitt som det har blitt. Det kan også være mulig å tilgi eller forsone seg med det som har skjedd uten å gjenopprette forholdet til den som har gjort oss vondt. Det kan være svært gode grunner til å ikke stole på denne personen igjen. Uansett er dette prosesser som ofte tar lang tid, noe Schancke (2021) påpeker. Hun understreker at ingen kan kreve at noen skal tilgi.

\section{Tilgivelse i faMilie og SAMLiVSRELASJONER}

Det er normalt at en krevende omstilling som et samlivsbrudd er, kan medføre vanskelige følelser og konflikter mellom de som en gang var et par. Det tåler barn fint en periode, men ikke hvis det blir langvarig. Da kan det skade barns utviklingsmuligheter. Med referanse til Dalai Lama-sitatet kan vi derfor si at foreldrenes indre individuelle liv, slik de støter sammen i forsøket på å samarbeide om felles barn, vil være medskaper til atmosfæren barna vokser opp i etter et samlivsbrudd. Det vil prege barnas barndom og utvikling på godt og vondt. I beste fall kan også barna lære av erfaringene og bli modne og kloke voksne. I verste fall kan barna selv stenge av rom i livet sitt fordi det blir for smertefullt og vanskelig. At foreldrene arbeider med seg selv og så langt det er mulig legger ned konfliktene med den andre forelderen, kan således være livsviktig for barna.

I en samlivsbruddsituasjon er det ofte vanskelig å fordele ansvar og skyld. Begge parter er gjerne «medskyldige» $\mathrm{i}$ bruddet, rett og slett fordi begge har vært 
medskapere til relasjonen slik den utviklet seg fra starten av. Man må kanskje tilgi den andre for noe, og seg selv for noe annet. Det samme gjelder i dagliglivet i familier med foreldre som lever sammen. Det skal mye til å leve i en familie uten at familiemedlemmene av og til sårer hverandre eller på ulike måter trår over hverandres grenser. Å kunne beklage og be om unnskyldning eller tilgivelse når man har gjort noe galt eller såret hverandre, er grunnleggende for å kunne reparere relasjonene og skape en sunn atmosfære i familien.

Chapman og Thomas (2007) har forsket mye på tilgivelse i samlivsrelasjoner. De har kategorisert ulike måter å tilgi på under det de kaller tilgivelsesspråk: $\AA$ beklage når man har gjort noe galt, å ta ansvar for eksempel ved å si at «det var galt av meg», å gjenopprette forholdet ved for eksempel å spørre hva man kan gjøre for å gjøre det godt igjen, å omvende seg ved å love at man aldri skal gjøre det igjen, og å be om tilgivelse. Tilgivelse er også ett av deltemaene i PREP kommunikasjonskurs for par, et av de ledende samlivskurstilbudene i Norge. Hovedinnholdet i kursene er utviklet på bakgrunn av forsknings- og utviklingsarbeid ved Universitetet i Denver, Colorado, men det er oversatt og bearbeidet for en norsk kontekst ved Modum Bad (se Lærum og Helskog, 2005 og PREP.no).

Hovedfokus i disse samlivspedagogiske tilnærmingene ligger på det å be om tilgivelse når man for eksempel har såret partneren sin eller på andre måter gjort urett. Utfordringen er imidlertid at den som venter på at andre skal beklage, ta ansvar, gjenopprette forholdet, omvende seg eller be om tilgivelse, risikerer å vente forgjeves. Det er ikke sikkert overtrederen en gang er klar over at han eller hun har gjort noe galt. I mellomtiden vil bitterhet, sinne, hat og hevntanker kunne tære på livet til den som venter, og skade relasjonen ytterligere. Ifølge Horribin kan det derfor være viktig å kunne tilgi selv om den som har trådt over streken, ikke nødvendigvis ber om unnskyldning. Kanskje forstår ikke denne personen selv hva han eller hun har gjort, eller hvordan det har virket på den andre.

\section{SKOLEN OG LERERUTDANNINGEN}

Tilgivelse er også relevant i skolen, og dermed i lærerutdanningen. Blant annet er det en av grunnverdiene i skolens formålsparagraf (Lovdata) og i Overordnet del av læreplanverket, og skal således ligge til grunn for alt arbeid i skolen. Det er dagligdags i skolen at barn og ungdom kommer i konflikt med hverandre, sårer hverandre og altfor ofte også mobber hverande. Også kolleger og studenter imellom, og mellom lærer og elev/student, kan det oppstå konflikter og uforsonlighet. Å håndtere dette på konstruktive måter krever såvel innsikt, kunnskaper og ferdigheter som medfølelse og klokskap. I forskningsartikkelen Pedagogisk arbeid med grunnverdien tilgivelse (Helskog 2021), drøfter jeg dette inngående. Et slikt arbeid fordrer at lærere, på samme måte som foreldre, begynner med seg selv og sine egne holdninger og væremåter når de skal tilrettelegge for et godt lærings- 
miljø med en tilgivende kultur i skolen. Å være en god rollemodell innbærer at man så selv forsøker å leve som man lærer. En lett omskriving av Dalai Lamas ord tydeliggjør poenget:

Så snart egenskapene kjoerlighet, medfolelse og uselviskhet er utviklet hos loereren, er han eller hun $i$ stand til å skape en atmosfare av fred og harmoni. Denne atmosfaren kan utvides fra loereren til klassefellesskapet, fra klassefellesskapet til samfunnet, og etter hvert til hele verden.

Av denne grunn valgte jeg i sin tid å la Dalai Lamas ord åpne boka «Dialogos praktisk filosofi i skolen. Veiledning for laerere og samtaleledere» (Helskog og Ribe 2009). Jeg fant at ordene i stor grad fanget essensen også for det filosofiske arbeidet som Dialogosbøkene legger opp til, der sann menneskelighet, klokskap og visdom er gjort til overordnede danningsidealer. En av tekstene, «Tilgivelse, takknemlighet og kunsten å holde fast ved det gode» (økt 51 i Helskog og Ribe 2008), er plassert i en kontekst der tilgivelse knyttes til nettopp visdom, der økende evne til å tilgi og forsones forstås som en komponent $i$ danningsprosessen og et uttrykk for dyp visdom.

\section{Det Globale SAMFUnNeT}

Dalai Lama snakker om at den som først har gjennomgått en indre forvandling, kan skape en atmøsfære omkring seg som til slutt kan utvides til hele verden. Det er en voldsom ambisjon som likevel har en jordnærhet og realisme ved seg. Tilgivelse er nemlig ikke bare relevant i familieliv, skole og lærerutdanning, men også på den mer utvidede samfunnsmessige arenaen, både lokalt, nasjonalt og globalt. Her kan den amerikanske teologen Frank Buchmans liv og virke stå som et eksempel, slik det er framstilt av Spoerri (1975). Buchmans personlige erfaringer med tilgivelse førte til et verdensomspennende arbeid med ledere i nærings- og arbeidsliv og politikk for å skape vilkår for fred både etter 1. og 2. verdenskrig.

Buchman ble født i 1878 i Pennsburg, USA. Arbeidet hans skjøt ifølge Spoerri (1975) fart med et sviende nederlag. Styret i institusjonen han ledet, hadde nemlig strammet inn pengesekken, og til tross for iherdige protester fra Buchman og andre, sto styret på sitt. «Han var så forbitret at han ble fysisk syk», skriver Spoerri (1975:20-25): Forvandlingen kom en dag han tilfeldigvis gikk inn i en liten kirke der 17 mennesker lyttet til en kvinne som snakket om tilgivelse. Med seg inn hadde han «stolthet, egenkjærlighet og hat». Med seg ut hadde han en følelse av «nytt, friskt liv», skriver Spoerri. Opplevelsen fører til at Buchman skriver brev til styremedlemmene og ber om tilgivelse for «sitt hat og sin vonde vilje» - en vilje som ødela både fellesskapet og mennesket selv. Prosessen ga ham en opplevelse av frihet og glede. Han beskriver den som om en fange har brutt ut av fengslet og blitt 
et fritt menneske. Kraften i denne erfaringen, skriver Spoerri, «satte mennesker og nasjoner i bevegelse».

Gjennom sitt samarbeid med lederfigurer verden over, arbeidet Buchman fra nå av iherdig for forsoning innad i og mellom stater. Metoden hans var enkel: Han oppfordret til personlig og ærlig erfaringsdeling ut fra idealer som er til forveksling sammenfallende med egenskapene Dalai Lama tar til orde for. Man skulle, så langt man klarte det, leve ut fra normene absolutt ærlighet, renhet, uselviskhet og kjærlighet. Erlighet, fordi løgn og maskespill splitter. Renhet, i betydningen rent hjerte, fordi grådighet og usunt begjær ødelegger mennesker. Uselviskhet, fordi stolthet og egoistisk ærgjerrighet isolerer, og kjorlighet, fordi det motsatte skaper splid og vond vilje. Utvikling av en tilgivende og forsonende livspraksis er en nødvendig konsekvens av en slik grunnholdning til andre mennesker, uavhengig av hvor i samfunnet man har sitt virke.

Med disse idealene som kompassnåler arbeidet Buchman med ledere i India, Kina, Japan, Europa, Sør-Afrika og USA. Tanken var at ved å begynne med lederne, ville grunnholdningene som ble utviklet også kunne bidra til brobygging og forsoning både innad og mellom statene. Han møtte blant annet Mahatma Gandhi mange ganger. I alt han gjorde, søkte han å forsone det privat-personlige med det offentlig-globale. Dersom man skal skape forandring i verden, må den enkelte først arbeide med seg selv og sine egne indre egenskaper, hevdet Buchman. Vi aner her også forbindelsen til de ofte siterte, og nå nærmest klisjeaktige ordene til Gandhi: Du må vare forandringen du vil se i verden.

\section{EN FELLESMENNESKELIG MULighet?}

Forvandlingen både buddhistiske Dalai Lama, hinduistiske Mahatma Gandhi og de kristne teologene Peter Horribin og Frank Buchman tar til orde for, har klare fellestrekk. Fra sine ulike livssynsmessige og politiske ståsteder tar de til orde for at den enkelte må begynne med seg selv. Gjennom en indre forvandling der hver og en av oss utvikler en tilgivende holdning og egenskaper som kjærlighet, uselviskhet og ærlighet, kan vi bli rollemodeller og tilretteleggere for fred og harmoni omkring oss, i familien, skolen og samfunnet. Tilgivelse kan således være en nøkkel til å skape et godt liv for oss selv og andre. Det kan bidra til å skape eksistensielle fellesskap på tvers av personlig, kulturell og religiøs forskjellighet. 


\section{LitTERATUR}

Chapman, Gary og Jennifer Thomas. 2007. Tilgivelsens fem språk. Lunde forlag. Helskog, Guro Hansen, Helle Myrvik og Kristin Tafjord Lærum. Kommer 2021. Fortsatt Foreldre. GODT NOK samarbeid etter samlivsbrudd. Oslo og Vikersund: Barne-, ungdoms- og familiedirektoratet og Modum Bad. Helskog, Guro Hansen. 2021. «Pedagogisk arbeid med grunnverdien tilgivelse. Mellom skolens formål og de unges erfaring». I Prismet nr 3/21 - dette nr.

Helskog, Guro Hansen, og Andreas Ribe. 2009. Dialogos. Veiledning for laerere og samtaleledere. Oslo: Fag og kultur.

Helskog, Guro Hansen, og Andreas Ribe. 2008. Dialogos. Praktisk filosofi i skolen. Elevbok. Oslo: Fag og kultur.

Horrobin, Peter. 2009. Guds universalnøkkel - tilgivelse. Be den mektigste bønnen på jord. Oslo: Luther Forlag.

Lovdata. 2008. Lov om grunnskolen og den vidaregåande opplaringa (opplaringslova). Kapittel 1, § 1-1. Formålet med opplaringa. Lastet ned den 07.09.2019 fra https:// lovdata.no/dokument/NL/lov/1998-07-17-61

Lærum, Kristin og Guro Hansen Helskog (red). 2005. Fra teknikk til holdning. Erfaringer med samlivsprogrammet PREP i Norge. Vikersund: Samlivssenteret Modum Bad

Markman, Howard J, Scott M. Stanley, Susan L. Blumberg. 2010. Fighting for Your Marriage. Jossey-Bass; 3rd edition

Meneses, C. W., \& Greenberg, L. S. 2019. Forgiveness and letting go in emotionfocused therapy. American Psychological Association. https://doi. org/10.1037/0000144-000

Schanche, Elisabeth. 2021. «Den vanskelige tilgivelsen.» I Prismet $\mathrm{nr} 3 / 21$ - dette nr.

Spoerri, Theophil. 1975. Stillhetens dynamikk. Om Frank Buchmans utfordring til vår tid. Oslo: Forlaget Ny verden.

Wade, N. W. Hoyt, Kidwell. J, \& Worthington, E. 2014. «Efficacy of psychotherapeutic interventions to promote forgiveness. A meta-analysis.» Journal of Consulting and Clinical Psychology, 82(1), 154-170. https://doi.org/10.1037/ a0035268 


\section{Ny bok om samarbeid mellom skole og kirke}

- til salgs fra høsten 2021

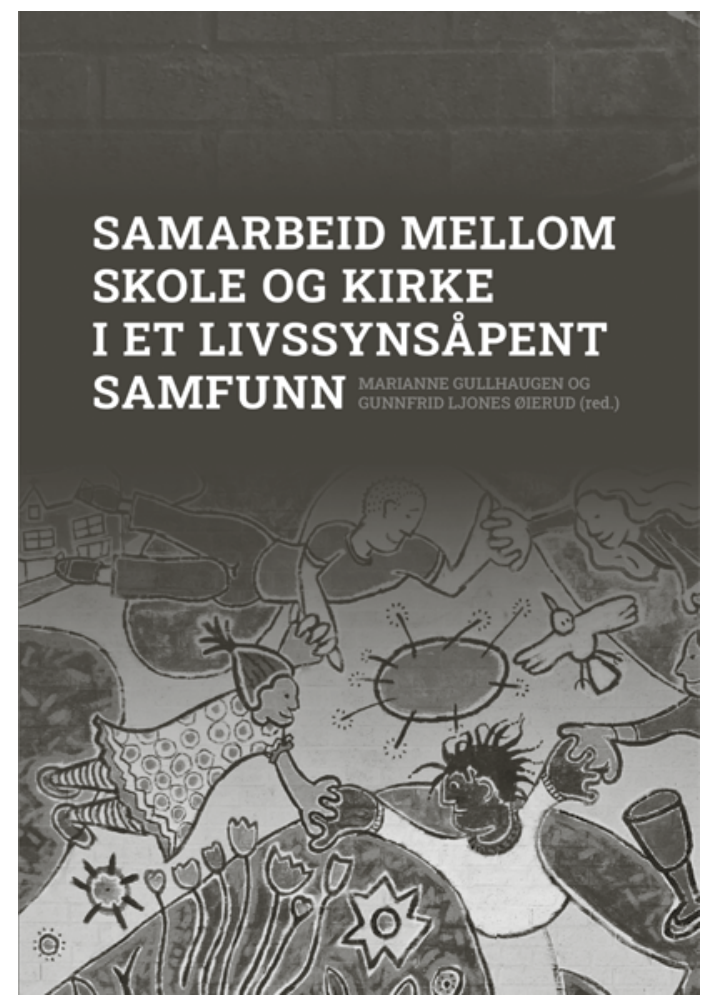

Redaktører: Marianne Gullhaugen og

Gunnfrid Ljones Øierud 192 Sider

ISBN: 978-82-8249-477-9

399,-

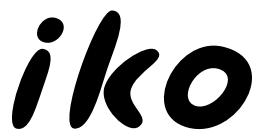

Boka kan kjøpes i nettbutikken på iko.no

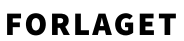

